\title{
Community Participation and Preparedness for Integrating Disaster Risk Reduction (DRR) in Managing Disasters A Study of Srinagar Floods (2014), India
}

\author{
Bupinder Zutshi, \\ Senior Fellow, Indian Council of Social Science Research, New Delhi, India, \\ Former Professor, Jawaharlal Nehru University, India
}

Doi:10.19044/esj.2020.v16n17p58～URL:http://dx.doi.org/10.19044/esj.2020.v16n17p58

\begin{abstract}
Sendai Framework of Action has emphasized on, community participation and preparedness, as a major strategy for Disaster risk-reduction (DRR), for managing disasters. It ensures that, effects of disasters are minimized and people are made, resilient for improved coping capacities, to attain resettlement at the earliest. Jammu \& Kashmir state experienced worst flood, during first week of September 2014, due to unprecedented and incessant rains and existing flood vulnerabilities. A total of 1.16 million population, out of 1.27 million population, of Srinagar Urban Agglomeration were, affected by the September 2014 floods. Present study, attempts to examine flood vulnerabilities and steps taken, by Jammu \& Kashmir, State Disaster Management Authorities (SDMA) and NGOs, for reducing identified flood vulnerabilities and creating conducive conditions, for adopting community participation and preparedness measures, to integrate disaster risk reduction strategies. The study is based on both secondary and primary sources of information. Secondary sources of information include, government measures adopted for reducing flood vulnerabilities. A primary field survey was conducted, among the flood affected families, to study community participation, preparedness and perception changes, in adopting Disaster Risk Reduction measures. Findings, from the study, indicate, that State machinery has been created for implementing Disaster-risk-reduction measures and community participation and preparedness has been sufficiently activated. However, awareness generation measures, like safety audits, implementation of building codes and development of emergency resettlement centres, are not effectively working. Although early warning system equipment, have been installed, but people are not aware, as to how, such warning will be communicated and what measures are required during warning period.
\end{abstract}


Keywords: Sendai Framework, Disaster Risk-Reduction Management, Community participation and preparedness, Emergency resettlement centers

\section{Introduction}

Several studies by scientific community have indicated that, Earth's climate is rapidly changing. The Intergovernmental Panel on Climate Change (IPCC) states that, "warming of the climate system is unequivocal," and its conclusion is supported by observations of increases in global air and ocean temperatures, widespread melting of snow and ice, and rising global mean sea level (IPCC, 2007c, p. 5).

The frequency and severity of weather- and climate-related hazards, has increased due to human activities, exposing more people and a greater value of assets to disasters. These extreme weather events, have impacted both natural and human systems. (Stern, 2006; IPCC, 2007c). Sendai Framework of Action, has rightly endorsed, Disaster risk-reduction management (DRM), through community participation and resilience measures, as a key to reduce the disaster related affects. Mainstreaming disaster risk-reduction management, within the policies and programmes of different sectors, ensures that, effects of disasters are minimized and people are made resilient, for improved coping capacities, to attain resettlement situation at the earliest.

DRM is therefore the key, to minimize the human fatalities, loss of building and other construction and infrastructure structures, agricultural crops, loss of animal and livestock. At the same time, it enables governments to ensure that these policies and programmes do not put people at risk. According to the UNISDR-2009, DRM is "the systematic process of using administrative directives, organizations and operational skills and capacities to implement strategies, policies and improved coping capacities, in order to lessen the adverse impacts of hazards and possibility of disaster".

"People are already experiencing impacts of climate change, through slow onset of changes, for example, sea level rise and greater variability in the seasonality of rainfall, and through extreme weather events, particularly extremes of heat, rainfall and coastal storm surges" (IPCC, 2012). At the same time, economic damage from climate-related extreme events and disasters has increased dramatically, in the last 50 years, with developing country economies being particularly badly hit. There has been significant rise in economic losses from disasters, for the Asia and Pacific region

The Sendai framework of action 2015-2030 (SFDRR) is now accepted as, a global policy framework, to represent the focused and coherent directions, undertaking, the complexities of the present world vulnerabilities to disasters. The plan entails mostly to reduce disaster risks and losses, incurred by making communities disaster resilient. This was considered a 
breakthrough on a global scale, after the HYGO Framework of Action, encompassing securing livelihoods, and reducing losses of the vulnerable communities. The Sendai framework involves, adoption of the model of integration, for the role of institution and investment, to lead to, decrease in losses caused, during an event of disaster and to increase preparedness and build a resilient community.

While it is clear that disaster-related shocks and stresses, undermine economic growth and development, there are many actions that governments and other agencies can take to reduce, the risks to lives, livelihoods and economies (Mitchell, T et.al; 2013). Poor people suffer the most from disasters, as they lack the capacity and resources to effectively cope with disasters. Risk management in policies and programmes, to reduce disaster risk reduction is vital, for helping to ensure, that most vulnerable people can access benefits of development (Mitchell, T and Tanner, T; 2006). Some people see mainstreaming, as a way to realize certain human rights, including the right to safety (Kent, G; 2001, Khan, D; 2013, Bahadur, A; 2008, Dutta, M, 2020). The impetus for mainstreaming risk in development, can also be linked to a government's fiduciary responsibility; Jackson makes this point when he notes, that mainstreaming risk is a government's, "duty to their citizens to maximise the utility of the public resources disposable to them, similar to a private company's fiduciary duty to maximise value to shareholders" ( Jackson, 2008).

Government of India, launched a comprehensive National Disaster Management Plan, (NDMP) prepared by the National Disaster Management Authority of India in 2016 (NDMA; 2016). The document was released by Prime Minister of India and it endorses, disaster risk reduction, a major necessity towards disaster management, by identifying vulnerable spots and vulnerable population groups. Before the onset of the National Disaster Management Plan, the DM Act 2005 (Disaster Management Act; 2005), was believed to be a milestone, owing to, a paradigm shift in the management of disasters in India. The shift was introduced in response to the disasters, which initially remained, relief centric and later the trajectory, led to the implementation and focus towards preparatory measures of mitigation and preparedness. It covers all components, under its umbrella protection of the livelihoods, losses and development of the community. The new NDMP focusses, to reduce disaster risk, disaster damage and losses and to create a disaster resilient society, focusing on the well-being of the people (Zutshi, Bupinder, 2019).

Sendai Framework states, four priority areas that needs immediate implementation by the countries. These four pillars are,

- Understanding disaster risk. 
- Strengthening disaster risk governance to effectively manage disaster risks.

- Investing in disaster risk reduction resilience measures.

- Enhancing disaster preparedness, for effective response and to build capacities for immediate and effective recovery, rehabilitation and reconstruction.

\section{Objectives of the Study}

The present study attempts, to;

- Examine flood vulnerabilities in Kashmir Valley and Srinagar city.

- Identify steps taken by Jammu \& Kashmir, State Disaster Management Authority (SDMA) and Non-Governmental Organizations (NGOs), in reducing flood vulnerabilities and creating conducive environment for implementing Disaster Risk Reduction (DRR) measures.

- Analyse, responses and perception changes, of community participation and preparedness, for adopting Disaster Risk Reduction strategies.

\section{Methodology and Sources of Data and other Information.}

The key informants of secondary sources of information were, officials from SDMA, Meteorological Department, Flood Control Department, Divisional Commissioner- Kashmir Division and Srinagar Municipal Development Authority. Information on flood vulnerable parameters and steps taken to mitigate these vulnerabilities, were collected from these departments. The information collected, were grouped into vulnerabilities, related to physiographic, geological, meteorological, structural and non-structural parameters. In addition to these secondary sources of information, other sources, include, several directions and judgements of Jammu \& Kashmir, High Court, to the state government on flood management. Previous research studies, newspaper clippings, research articles and other related published and unpublished materials, were also used. In addition, discussions with NGOs and other civil society actors was conducted, in order to get a clearer, perspective of the DRR measures and their acceptance and adoption by the community.

A primary field survey of September 2014 flood, affected households, from 5 areas/ localities of Srinagar city, was conducted in May-June 2016 and the survey was again followed up, in September-October 2019, in the same areas for the same households. These 5 areas/ localities were submerged, under floods for 7-10 days, during September 2014 floods. Out of the 5 areas/ localities, four localities namely, Mehjoor Nagar, Jawahar Nagar, Gogji bagh 
and Rajbagh, were residential localities and Lal Chowk was shopping area/trade center. A total of 125 flood affected households, from the 5 areas/ localities, was randomly selected, from the strata of severely, moderately and mildly affected areas. A random sample of 50 households each, from severely and moderately flood affected areas/ localities and 25 households from mildly flood affected areas, was selected for the survey. Out of 125 households selected, for the survey, 44 houses of these households, were completely collapsed, 61 houses were submerged for 7 -10 days and 20 trade shops were submerged for 7-10 days in the floods. ( Refer Table No 1)

The field study methods, utilized include field observation, focused group discussion and triangulation methods, utilised for the validation of the information, provided by flood affected families. Structured questionnaires, were prepared having, both quantitative and qualitative components, with both open-ended and multiple choice questions -answers.

Research investigators, selected for the survey were, imparted special training for adherence to ethical issues, while conducting the field survey. The research team initiated the data collection process and field observation, in compliance with the ethical code of conduct, as specified by the Indian Council of Social Science (ICSSR). Informed consent from the respondents was sought, prior to data collection, to ensure that the rights of the individuals and groups, participating in the survey were neither violated nor trespassed upon. One of the major limitations, experienced by the research team was the lack of information on baseline data.

Table 1: Srinagar City

Sample Design for Field Survey of Flood affected Households

\begin{tabular}{|c|c|c|c|c|c|c|c|}
\hline \multirow[t]{2}{*}{$\begin{array}{l}\text { Areas/ } \\
\text { Localities }\end{array}$} & \multicolumn{4}{|c|}{$\begin{array}{c}\text { September } 2014 \\
\text { Flood affected Households }\end{array}$} & \multicolumn{3}{|c|}{$\begin{array}{l}\text { Nature of Damage, to Property of } \\
\text { Selected Flood Affected Households }\end{array}$} \\
\hline & All & Severely & Moderately & Mildly & $\begin{array}{l}\text { House } \\
\text { Collapsed }\end{array}$ & $\begin{array}{l}\text { House } \\
\text { Submerged }\end{array}$ & $\begin{array}{l}\text { Trade Shops } \\
\text { Submerged }\end{array}$ \\
\hline Mehjoor Nagar & 25 & 10 & 10 & 5 & 10 & 15 & \\
\hline Lal Chowk & 25 & 10 & 10 & 5 & & 5 & 20 \\
\hline Jawahar Nagar, & 25 & 10 & 10 & 5 & 7 & 18 & \\
\hline GogjI bagh, & 25 & 10 & 10 & 5 & 15 & 10 & \\
\hline Rajbagh & 25 & 10 & 10 & 5 & 12 & 13 & \\
\hline All Areas & 125 & 50 & 50 & 25 & 44 & 61 & 20 \\
\hline
\end{tabular}

Source: Field Survey by Research Team conducted during May-June 2016 and SeptemberOctober 2019.

Flood Vulnerabilities in Kashmir Valley India Physiographic, Geologic structure and Meteorological vulnerabilities

Kashmir Valley, in Jammu and Kashmir, Union Territory of India, is highly prone to floods, due to its physiographic and geologic structure. Kashmir Valley is a deep, asymmetric basin, delineated from the adjoining mountain systems, on the basis of drainage network and its catchment basin 
(Raza Moonis, 1978). The valley of Kashmir includes, all land lying, within the water divides, formed by the Pir-panjal Mountain ranges, north Kashmir ranges and great Himalayan ranges. These mountain ranges encircle great synclinal trough, occupied by Jhelum River in Kashmir Valley (Raza Moonis, 1978). Average height of Kashmir Valley is about 1850 meters, above sea level, but the surrounding mountains, are generally snow clad and they rise up to 3000 to 4000 meters, above sea level (Census of India, 1988) (Refer Map No.1).

Like all sedimentary basins, the valley has a combination of depositional and erosional features. Low lying waterlogged areas and Jhelum river channel are subject to, receiving layer after layer of fine silt and coarse gravel that increases, water level of Jhelum river during monsoon period. During August-September months every year, usually incessant rainfall for 15-20 days occurs, during withdrawal of monsoon period from this region. This enhances the flood conditions in the low-lying areas of Kashmir Valley, as well as in its capital, Srinagar city. Srinagar city has embankment walls around the city, supported by construction of bunds on both sides of its river channel. However these embankment walls are old constructions and it breaches sometimes, owing to higher water discharge from its upper reaches, due to incessant rainfall.

Map 1: Kashmir Valley Physiography and Jhelum Basin Drainage Network

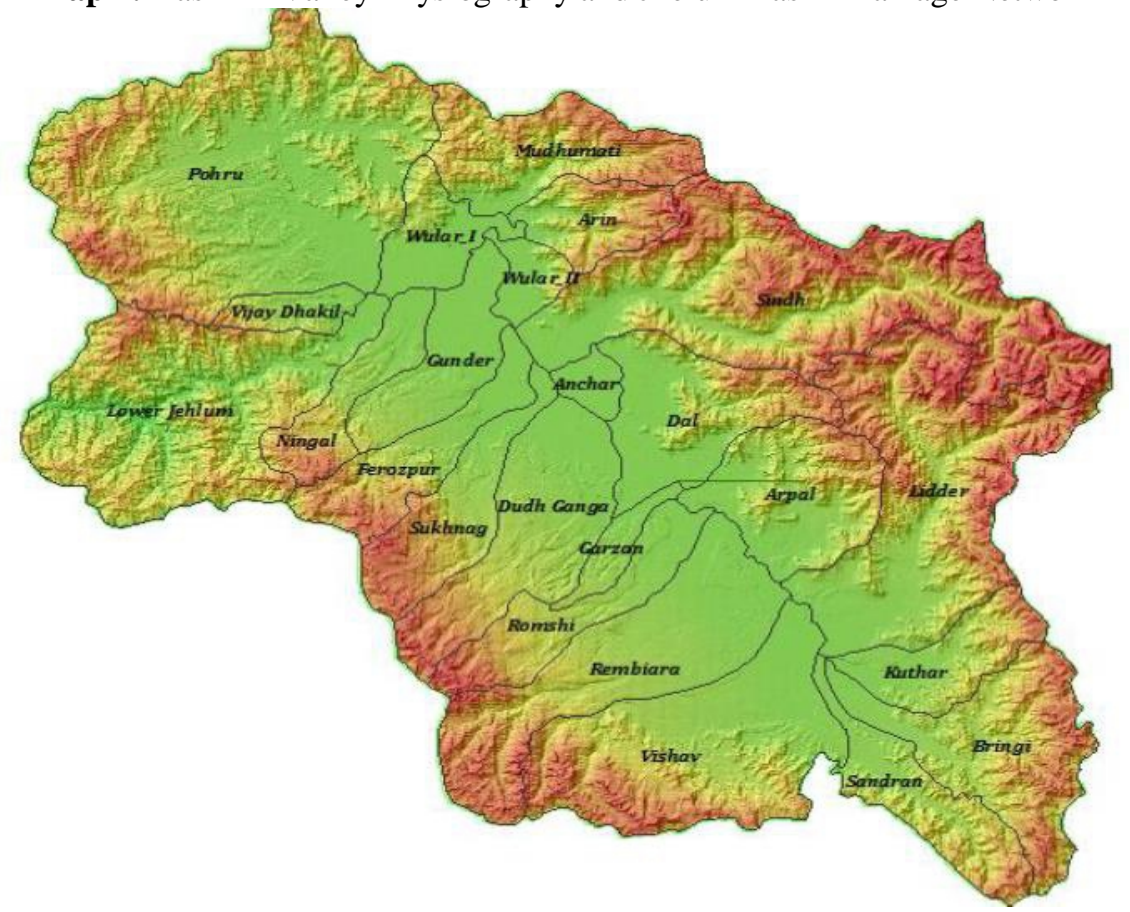

Source: Atlas of Jammu \& Kashmir, Census of India -1981 
Jammu \& Kashmir experienced, the worst floods in the past 60 years, during first week of September 2014, due to unprecedented and incessant rains, which was considered as one of the extreme weather events. "The synchronization of movement of westerly winds in the extreme north, with the passage of monsoon disturbances in the lower latitudes, caused heavy to very heavy rainfall along the foothills of the Himalaya, and adjoining areas of Jammu \& Kashmir" (Kamaljit, Ray et.al, 2015). Continuous rainfall from Ist September - 6th September 2014, with a record of 30 hour of continuously incessant rainfall from 3rd September 2014, broke the record of many decades. Majority of rainfall stations, in Kashmir valley, recorded deviation of more than +6000 percent rainfall for the 4 days (3-6th September 2014), as compared the norm of rainfall, for the same days recorded from 1970-2000 (Refer Table No 2).

Table 2: Rainfall reported (mm) over stations located in Kashmir Valley during 3-6

September 2014

\begin{tabular}{|l|l|c|c|l|}
\hline District & Station & $\begin{array}{l}\text { Actual Rainfall } \\
\text { reported during }\end{array}$ & $\begin{array}{l}\text { Normal Rainfall } \\
\text { during 3-6 }\end{array}$ & $\begin{array}{l}\text { Deviation } \\
\text { from Norm } \\
\end{array}$ \\
& & 2014 September & $\begin{array}{l}\text { September 2014 } \\
\text { 3* }\end{array}$ & \\
\hline Anantnag & Kukernag & 415 & 5.5 & 7449 \\
& Pahalgam(AWS) & 217 & 6.9 & 3045 \\
\hline Baramulla & Baramula (AWS) & 185 & 1.9 & 9637 \\
& Gulmarg & 366.8 & 6.5 & 5543 \\
\hline Kulgam & Kulgam (AWS) & 346 & 9.8 & 3431 \\
& Qazigund & 599.8 & 5.4 & 11007 \\
\hline Awantipur & Awantipur (IAF) & 208.1 & - & - \\
& Malangpura (AWS) & 266 & - & - \\
\hline Shopian & Shopian & 335 & 5 & 6600 \\
\hline Srinagar & Rambagh (AWS) & 140 & 2.6 & 5285 \\
\hline Kupwara & Kupwara & 131.8 & 3.1 & 4152 \\
\hline
\end{tabular}

Source: Kamaljit Ray*, S. C. Bhan and B. K. Bandopadhyay, "The catastrophe over Jammu and Kashmir in September 2014: a Meteorological observational analysis, CURRENT SCIENCE, VOL. 109, NO. 580 3, 10 AUGUST 2015

**Normal Rainfall of these stations have been calculated from 1970- 2000 for the same days.

In addition to the physiographic, geologic structure and meteorological vulnerabilities for floods in Kashmir Valley, there are several structural and non-structural flood vulnerabilities.

\section{Structural Vulnerabilities}

- Inadequate carrying capacity due to design and poor maintenance of, embankments/bunds, flood walls and flood levees and flood channels,

- Inadequate channel improvement desilting/dredging of rivers, dams, reservoirs and other water storages, 
- Blockage of flood water channel, due to urban construction, poor catchment area treatment/afforestation and anti-erosion works,

- Improper alignment, location, design and provision of waterway i.e. vents, culverts, bridges and causeways in national highways, state highways, district and other roads and

- Railways embankments and its poor inspection, rehabilitation and maintenance.

\section{Non-Structural Vulnerabilities}

Unabated urban expansion and change of land use and land cover on both sides of the river Jhelum in Srinagar city has taken place during 19712013 period. Based on satellite data and existing toposheets, a comparative statistics of the Srinagar city has been developed. It clearly reflects a drastic change in land use and land cover from 1971-2013 period. Srinagar city buildup area, has increased from $2.45 \%$ in 1972 to $39.08 \%$ in 2013 . The overall percent increase in build-up area was $36.63 \%$ during this period. Consequently area under agricultural, plantation and horticulture activities have decreased continuously. Several water bodies have even disappeared. Even areas around flood channels were converted into build-up areas. All these activities have, hindered free flow of Jhelum river in Srinagar city.

(Refer Map No 2 and Table No 3)

Table 3: Srinagar City ( Kashmir Valley) Land use- Land Cover (LULC) ( 1972-2013)

\begin{tabular}{|c|c|c|c|c|c|}
\hline \multirow{2}{*}{ LULC } & $\begin{array}{c}\text { Area } \\
(\boldsymbol{\%})\end{array}$ & Area(\%) & Area (\%) & Area (\%) & $\begin{array}{c}\text { Percentage } \\
\text { Change 1972-2013 }\end{array}$ \\
\cline { 2 - 5 } & $\mathbf{2 0 1 3}$ & $\mathbf{2 0 0 5}$ & $\mathbf{1 9 9 2}$ & $\mathbf{1 9 7 2}$ & 36.63 \\
\hline Built up & 39.08 & 33.23 & 12.98 & 2.45 & -24.43 \\
\hline Agriculture & 22.95 & 25.37 & 36.32 & 47.38 & 11.84 \\
\hline Horticulture & 15.04 & 8.21 & 7.00 & 3.20 & 4.14 \\
\hline Aquatic Vegetation & 8.59 & 8.33 & 7.92 & 4.45 & -2.30 \\
\hline Water & 5.23 & 5.62 & 6.13 & 7.53 & -13.08 \\
\hline Plantation & 5.10 & 11.61 & 16.59 & 18.18 & -4.61 \\
\hline Forest & 1.99 & 3.40 & 4.78 & 6.60 & -1.91 \\
\hline Barren & 0.53 & 1.63 & 2.04 & 2.45 & 0.43 \\
\hline Scrub land & 0.49 & 0.22 & 0.12 & 0.06 & -4.22 \\
\hline Pastures & 0.45 & 1.23 & 4.10 & 4.66 & 0.24 \\
\hline Exposed Rock & 0.41 & 0.34 & 0.30 & 0.16 & -0.38 \\
\hline River bed & 0.09 & 0.18 & 0.23 & 0.47 & -2.35 \\
\hline Karewa & 0.06 & 0.63 & 1.49 & 2.41 & \\
\hline TOTAL & 100.00 & 100.00 & 100.00 & 100.00 & \\
\hline Source: NRSC ISR & & & \\
\hline
\end{tabular}

Source : NRSC, ISRO and Department of Ecology, Environment and Remote Sensing, Government of Jammu \& Kashmir, A SATELLITE BASED RAPID ASSESSMENT ON FLOODS IN JAMMU \& KASHMIR - SEPTEMBER, 2014, Table No.7, pp59. 
Map 2: Srinagar City- Land use, Land Cover Changes (1972- 2013)

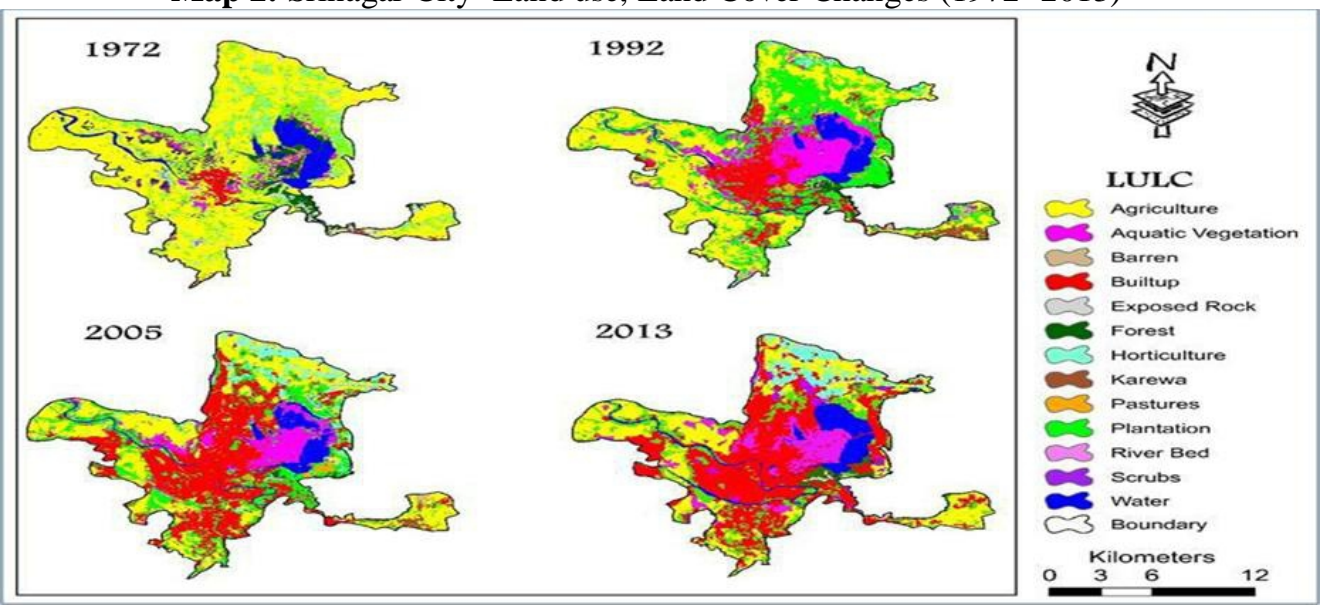

Source: : NRSC, ISRO and Department of Ecology, Environment and Remote Sensing, Government of Jammu \& Kashmir, A SATELLITE BASED RAPID Assessment

Owing to inadequate capacity (Due to continuous sedimentation of Jhelum river bottom, without drudging activities adopted for several decades) of the Jhelum river and its tributary rivers to contain within their banks, the high flows brought down from the upper catchment areas following heavy rainfall, lead to flooding of villages. The existing embankment/bunds on river Jhelum in Srinagar city, could not be contained in the existing channels of Jhelum river. As a result of this, nearly 90 breaches at several embankments were found at several places in and around Srinagar city. These breaches flooded nearly 3/4th of Srinagar city and its lower level habitations.

Thus a combination of physiographic, geologic structure, meteorological, structural and non-structural vulnerabilities were responsible for the September 2014 flood, in Kashmir Valley. Most populated areas and high density areas submerged in Srinagar city. Ninety one percent population of 1.27 million population of Srinagar Urban Agglomeration, was affected by the September 2014 floods. (NRSC-ISRO, 2014, p54). Out of 227.41 square kilometres areas of Srinagar city agglomeration, 118.75 square kilometres of areas constituting $52 \%$ of the Srinagar city areas, was completely inundated/ submerged for 10 days. The distribution of fully inundated areas in Srinagar city were, residential (28.11 Sq. Kms), agriculture (34 Sq. Kms) commercial (32.21 Sq. Kms), Open areas (12.39 Sq. Kms) and the rest areas including restricted areas (Military areas), hospitals, police stations, educational and areas with administrative buildings. (Zutshi, Bupinder 2018).

(Refer Table No 4) 
Table 4: Srinagar Urban Agglomeration,

Flood Affected Land use/ Land Cover (September 2014)

\begin{tabular}{|l|c|c|}
\hline \multicolumn{1}{|c|}{ Land use/ Land Cover } & Area & $\begin{array}{c}\text { Percent Area Affected by } \\
\text { Floods to total inundated } \\
\text { area }\end{array}$ \\
\hline Agriculture & 34.10 & 28.71 \\
\hline Commercial & 32,21 & 27.12 \\
\hline Residential & 28.11 & 17.77 \\
\hline Open Land & 12.39 & 10.43 \\
\hline Restricted Area & 4.05 & 3.41 \\
\hline Education & 1.90 & 1.60 \\
\hline Residential + Commercial & 0.58 & 0.48 \\
\hline Medical & 0.53 & 0.46 \\
\hline Others & 4.88 & 4.10 \\
\hline All Flood Affected Area & $\mathbf{1 1 8 . 7 5}$ & $\mathbf{1 0 0 . 0 0}$ \\
\hline Total Srinagar Area & $\mathbf{2 2 7 . 4 1}$ & \\
\hline
\end{tabular}

Source : NRSC, ISRO and Department of Ecology, Environment and Remote Sensing, Government of Jammu \& Kashmir, a satellite based rapid assessment on floods in Jammu \& Kashmir - September, 2014, Table No.7, pp59.

The flood was termed as one of the worst floods by the then government in last 60 years. Dr. Omar Abdullah, the then Chief Minister of Jammu \& Kashmir state had to concede that, "I had no government for the first 36 hours as the seat of establishment was wiped out" (The Daily Excelsior , 7th September, 2014).

An analysis of human fatalities due to floods, in Kashmir valley, as compared to the national average depicts more deaths, thereby suggesting, lack of disaster management policy and disaster risk-reduction strategies in the state. Jammu and Kashmir has witnessed 76 flood events during 19782006 periods, and it ranked 13 among other states of India in terms of number of flood events (Omvir Singh, 2013). The state recorded 1,365 fatalities and 1,563 persons with injuries, missing and other causalities between 1978-2006 periods. Flood death rates recorded were significantly high as compared to national average for the two decennial periods as well as for the overall selected period, indicating least disaster risk reduction strategies adopted by the state of Jammu and Kashmir.

(Refer Table No 5 and 6)

Table 5: Flood Events, Fatalities, Injuries and Causalities - 1978-2006

\begin{tabular}{|c|c|c|c|c|c|c|}
\hline \multirow{2}{*}{ State } & \multicolumn{3}{|c|}{ Flood Events } & \multicolumn{2}{c|}{ Fatalities } & \multicolumn{2}{c|}{$\begin{array}{c}\text { Injuries, Missing, } \\
\text { Causalities }\end{array}$} \\
\cline { 2 - 7 } & No & Rank & No & Rank & NO & Rank \\
\hline Jammu \& Kashmir & 76 & 13 & 1365 & 13 & 1563 & 14 \\
\hline
\end{tabular}


Table 6: Flood Death Rates Per million population at decennial intervals

\begin{tabular}{|c|c|c|c|c|}
\hline State & $\mathbf{1 9 7 8 - 8 7}$ & $\mathbf{1 9 8 8 - 9 7}$ & $\mathbf{1 9 9 8 - 2 0 0 6}$ & $\mathbf{1 9 7 8 - 2 0 0 6}$ \\
\hline Jammu \& Kashmir & 35 & 146 & 3 & 135 \\
\hline India & 23 & 18 & 15 & 44 \\
\hline
\end{tabular}

Source: Omvir Singh, Manish Kumar, "Flood Events, fatalities and damages in India from

1978-2006", published online $16^{\text {th }}$ July 2013, Springer Science + Business Media,

Dordrecht, 2013

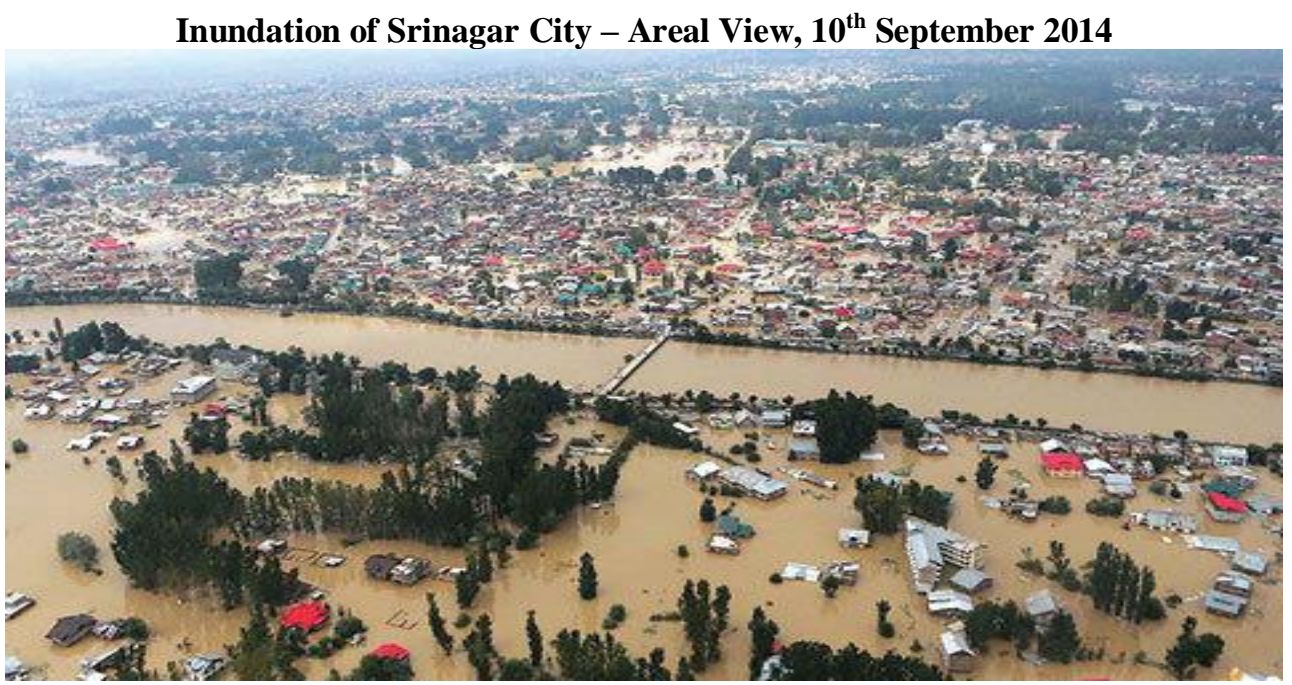

Source: National Remote Sensing, Department of Ecology, Environment and Remote Sensing, Government of Jammu \& Kashmir

\section{Flood Disaster Management Post 2014 Floods}

Divisional Commissioner of Kashmir Division is also Ex-Officio, Chairperson of Jammu \& Kashmir, State Disaster Management Authority (SDMA). A detailed discussion with the SDMA, Chairperson indicated, that the state has taken several steps after the September 2014 floods, that are in sync with the National Disaster Management Plan (NDMP) and other measures stipulated in the Disaster Management Act of 2005. The measures adopted by the SDMA were to infuse, both protective and preparedness measures and create community awareness, participation and preparedness to meet any future challenges of flood disasters in Kashmir Valley. The measures adopted were as follows;

\section{Development of Early Warning System}

High technology weather forecasting from Japan (Doppler radar) has been set up in 2015 at the Srinagar meteorology office. It has an areal coverage of 100 square kilometers. The Doppler radar has a capacity to predict, the volume, amount and type of precipitation, up to a maximum of six hours period. This weather radar technology employs Pulse-Doppler radars, which 
are capable of detecting the motion of rain droplets in addition to the intensity of the precipitation ( Douglas, R. H., 2000).

Both types of data can be processed and analyzed to determine the intensity, movement of storms and their potential to cause devastation. Thus, in case of natural disasters like cloudburst and floods, the Doppler weather radar may be able to forewarn people so as to minimize the loss of life and property. Besides the weather forecasting, Irrigation and Flood Control (IFC) Kashmir, has developed an android mobile application "IFC KASHMIR" developed by Dreamcode Developers, in collaboration with IFC Kashmir, which helps people in having, the levels of water at different gauges, through a click and makes them aware of ground situation.

However, it is not sufficient to have appropriate and timely warning that reaches target groups; it is also essential that the local population know, how, to react and what to do in emergencies. This depends on the extent to which warning services are decentralized and people prepared to adopt mitigative measures. Realigning warning systems to addressing community needs; implies that warning authorities have to engage communities to know those needs, recognize people's personal contacts, assess risks and manage public expectations of the warning system. Such network is still weak.

\section{Protective and Preparedness Measures adopted Post Floods 2014 I. Drudging and de-siltation of Jhelum River Channels}

Dredging has been completed for the targeted 38,100 cubic meters in the flood spill channel from Padshahibagh in Srinagar to Wullar lake in Bandipora district of north Kashmir as per the statement, given by state administration to Hon'ble High Court of Jammu \& Kashmir. Several reputed companies were involved in the dredging and de-siltation works of Jhelum river channels (The Tribune, Newspaper, June 02, 2017) ${ }^{5}$.

Another major cause for reduction in the carrying capacity of discharge water, during heavy floods was identified as plantation of trees, along the river course, which hindered the free flow of water discharge both in the tributary areas as well as for the main Jhelum river basin. Earlier on February, 2015, High court of Jammu and Kashmir constituted a high-level committee, headed by Divisional Commissioner, Kashmir Division, directing, to initiate a drive for removing all the encroachments from banks of Jhelum river and other water bodies. High Court of Jammu and Kashmir gave strong directions to state authorities and concerned department to clear Jhelum river courses, from

\footnotetext{
${ }^{5}$ Observing that it is because of the "inefficiency" of the authorities of the Irrigation and Flood Control (I\&FC) Department that floods in 2014 caused "havoc" in Kashmir, the High Court has directed the Chief Engineer to complete the phase-I of dredging of the Jhelum river by September 2017.
} 
such tree plantation, so that free flow of water is not hindered. As per norms, of flood department, all trees were required to be cleared within specific periods, from all tributary rivers and for main Jhelum river to make river Jhelum flow free. Information collected from government sources and the depositions made by government, before Hon'ble High Court indicated, significant progress has been made in clearing river course from such plantation of trees. A total of 357,127 trees have been removed in Kashmir division, from the tributary river courses. (Refer Table No. 6)

\section{Removal of Encroachment}

Jammu and Kashmir High Court has empowered all district magistrates to demolish constructions, that are seen coming up within the prohibited areas, of river Jhelum and its tributaries in Kashmir Valley. The Court also stayed, all constructions, on the river banks right from its source in, Verinag spring in South Kashmir to Uri gorge in North Kashmir. These directions were passed citing, an expert committee report on how encroachments on river Jhelum and its tributaries caused the devastating flood of September 2014. Deputy Commissioner Anantnag, while citing the expert committee report, had notified that out of total width of river Jhelum, only one-fifth has been left out without encroachments and all embankments have been breached particularly in Anantnag, Bijbehara districts and villages of other tehsils of South Kashmir. The report said, on account of encroachments, by way of plantations and constructions, breaches have occurred leading to deluge which has resulted in the catastrophe in Kashmir Valley during September 2014. On the basis of the report, the District Magistrate (DM) had directed all encroachers to remove plantations and constructions along river Jhulem and its tributaries-Lidder, Arpath, Brengi, Vaishav, Sandran, Vethvetrsoo-within 15 days. These encroachers removed the encroachments, within the stipulated period. Pertinently, J\&K, High Court has stayed constructions within 200 meters of river tributaries of Jhelum river.

The deposition before J\&K, Hon'ble High Court identified 1146 illegal structures and majority of them were in Srinagar district. Out of identified illegal structures 687 (both temporary and permanent) structures have been removed in addition to removal of 560 boundary walls which acted as hindrance to the main course of the rivers.

(Refer Table No 7) 
Table 7: Encroachment- Trees and Unauthorized Construction removed from River Courses

\begin{tabular}{|c|c|c|c|c|c|c|}
\hline \multirow[t]{2}{*}{ District } & \multirow{2}{*}{$\begin{array}{l}\text { Trees } \\
\text { removed } \\
\text { from } \\
\text { river } \\
\text { banks }\end{array}$} & \multicolumn{2}{|c|}{ Structures for Removal } & \multicolumn{3}{|c|}{ Structures Demolished } \\
\hline & & Identified & Removed & Permanent & Temporary & $\begin{array}{l}\text { Boundary } \\
\text { Wall }\end{array}$ \\
\hline Pulwama & & 213 & & & & \\
\hline Srinagar & & 816 & 687 & & & \\
\hline Bandipore & & 84 & & & & \\
\hline Baramula & & 33 & & & & \\
\hline $\begin{array}{l}\text { Kashmir } \\
\text { Division }\end{array}$ & 357,127 & 1146 & & 130 & 410 & 560 \\
\hline
\end{tabular}

Source: Deposition of State Government,

before Hon'ble High Court stated in local Newspapers

\section{Preparedness for Evacuation in case of Disaster Eventuality}

The state government and SDMA was not at all ready for rescue and evacuation during floods of September, 2014. No efforts were made to evacuate the flood affected victims as emergency boats were not ready to evacuate flood victims. Helicopter services, inducted for evacuation were very few, in view of the scale of devastation and number of marooned population. Even basic relief service like drinking water, medicines, essential supplies of food and clothes, were not made available for initial 3-4 days, after flooding of Srinagar city. Nor, were any Emergency Operation Centers (EOC's), identified for immediate rehabilitation and support for flood victims. It was only due to community resilience and support by civil society and army, that people got saved from this scale of tragedy. In the wake of any eventuality in future, state has now, identified few Emergency Operation Centers (EOC'S), which will act as Multi-Purpose and Multi-Disaster Utility Shelters to resettle people in case of future emergency during such calamity.

Identified Emergency Operation Centers (EOC) acting as Multipurpose and Multi-Disaster Utility Shelters, have been under progress, at different stages as per information supplied by SDMA authorities.

(Refer Table No.8)

Table 8: Identified Emergency Operation Centers for

Relief and Evacuation in Kashmir Division

\begin{tabular}{|l|l|l|}
\hline District & $\begin{array}{l}\text { Location of Emergency Operation } \\
\text { Center for Multi-purpose and Multi- } \\
\text { disaster Utility Shelter }\end{array}$ & Remarks \\
\hline Pulwama & Old Development Commissioner office & Has sufficient facilities \\
\hline Baramula & Sangribala site located at hillock & Well connected with other areas \\
\hline Srinagar & $\begin{array}{l}\text { Sanat Nagar (SMI Convention Center) } \\
\text { Humhama (GO'S Mess) } \\
\text { Khimber. }\end{array}$ & $\begin{array}{l}\text { All Centers have requires services } \\
\text { and facilities }\end{array}$ \\
\hline
\end{tabular}




\begin{tabular}{|l|l|l|}
\hline Kupwara & Nagnihal Pura & $\begin{array}{l}\text { Mooted as spot for EOC but not } \\
\text { developed as yet. }\end{array}$ \\
\hline Budgam & Rangreth & $\begin{array}{l}\text { State of the art EOC proposed but } \\
\text { construction yet to start. }\end{array}$ \\
\hline Ganderbal & $\begin{array}{l}\text { Office Building of I\&FC } \\
\text { Dignibal (identified as new site) }\end{array}$ & Construction yet to start \\
\hline Bandipore & Guest House Bandipore & Identified but facilities yet to start \\
\hline Shopian & Padpanen & Land identified \\
\hline
\end{tabular}

\section{Capacity Building and Awareness}

Training and capacity building of NGOs/CBOs, has been found to be the most effective tool of reducing disaster vulnerabilities. It should be endeavour of government's, Non-Government Organisations (NGOs) and Community Based Organization (CBOs), to create a trained cadre of officers/officials/ staff of different departments, who are directly involved in disaster management. In this direction the role of various institutions, need to be highlighted, since disaster management involves multi-stakeholders and as such, needs to be dealt with accordingly. The Universities, Engineering Colleges, Polytechnic Colleges, Medical Colleges/Regional Institutes of Health and Family Welfare, Revenue Training Institute, Police Academy/Police Training Centres, etc; should be roped in, to impart training to the various stakeholders. In addition, curriculum for students at school, college and university level, should have chapters on disaster management to be taught by both professional and trained teaching staff.

SDMA stated that after flood disaster 2014, several steps have been taken to build capacities of NGOs and CBOs, so that they can launch awareness generation campaigns and programs on Disaster Management among the community and other stakeholders. In this direction the Disaster Management Centre of Jammu \& Kashmir Institute of Management and Public Administration (IMPA), a premier institute of training for government staff, has been strengthened /upgraded in terms of infrastructure and manpower. IMPA has trained all relevant stakeholders and developed their capacities to infuse, disaster risk reduction strategies at the grassroots level.

The methods of awareness generation by NGOs and CBOs among the community include;

- Knowledge sharing of following early warning protocols.

- Promotion of Kashmiri folk theatre, such as Bhand-Pather, integrating the art with the theme of disaster risk reduction.

- Launching awareness campaign, regarding safety measures against potential hazards using, media, mobile apps, campaigns, development and distribution of leaflet, posters, meetings and workshop on priority basis. 
- Developing multi-hazard IEC material, for publications and distribution.

- Formulate literature of do's and don'ts, for building construction codes in local /vernacular languages.

- Dissemination of upgraded seismic resistant building construction knowledge among community.

- Educate public, in basic response measures during natural calamity, as well as during man-made disasters.

- Networking with community and the concerned authority, to share knowledge and best practices on effective approach.

- Sharing information on the anticipation hazard with accuracy.

\section{Community Participation and Preparedness}

The efforts of DRR strategies and measures adopted by SDMA and other government departments, need to be communicated to community, so as, to make them participative for ensuring protective and preparedness measures are adopted at community levels. Role of NGOs and CBOs, in making community awareness is the key for successful participation of all stakeholders. Several measures were taken by SDMA, government departments, NGOs and CBOs, post September 2014 flood to inculcate, DRR measures among community and other stakeholders. An attempts was made with help from field survey to find out, whether these measures have yielded the desired results in creating community institutions for DRR.

Community participation and preparedness were grouped into three aspects (i) knowledge and awareness about DRR , (ii) status of DRR and (iii) community participation and Prepardness. As expected knowledge and awareness about DRR was not at all existing prior to September 2014. But significant changes in the knowledge and awareness about DRR measures were conducted by government, were found in May-June 2016, which has further improved in September-October 2019. Significant proportion of respondents, have knowledge of government measures of installation of Early Warning system and its effectiveness in making people prepare for emergency evacuation. Community is aware of government efforts of strict compliance of rules and regulations of not, encroaching river channels and flood channels. Knowledge about de-silting and drudging has also increased over periods of time. This has ensured implementation of zero tolerance towards illegal encroachments in the river channels and flood channels. However knowledge and awareness related to safety nets, safe evacuation and conduction of mock drills are still poor.

A significant proportion of respondents clearly stated that status and compliance of DRR rules and regulations related to structural and non- 
structural parameters have been implemented over periods of time. However, awareness generation measures like safety audits, implementation of building codes and development of emergency resettlement centres are not being implemented effectively.

Indicators related to community participation and preparedness, depicts mixed results. Sixty five percent respondents had participated in the training programmes conducted by NGOs/ CBOs and other government departments in 2019, as compared to $32 \%$ in 2016. Seventy eight percent respondents have developed networks to seek support from NGOs/ CBOs during emergencies. Ninety one percent respondents have developed capacities of their family members to face disaster related eventualities. However capacities developed among respondents to act appropriately after early warning system were still weak. Similarly, disaster resilient building codes were not adopted by $80 \%$ of respondents.

(Refer Table No 9)

Table 9: Surveyed Respondents in Srinagar City Participation and Preparedness of Disaster Risk Reduction Measures (Percentage)

\begin{tabular}{|c|c|c|c|c|c|c|}
\hline \multirow[t]{2}{*}{ Indicator } & \multicolumn{2}{|c|}{$\begin{array}{c}\text { Before September } \\
2014 \text { Flood } \\
\text { N: } 125 \text { (Percent) }\end{array}$} & \multicolumn{2}{|c|}{$\begin{array}{l}\text { May-June } 2016 \\
\text { N: } 125 \text { (Percent) }\end{array}$} & \multicolumn{2}{|c|}{$\begin{array}{c}\text { September- } \\
\text { October } 2016 \\
\text { N: } 125(\%)\end{array}$} \\
\hline & Yes & No & Yes & No & Yes & No \\
\hline $\begin{array}{l}\text { Knowledge and Awareness About } \\
\text { DRR Measure of Government } \\
\text { - } \quad \text { Knowledge about Early Warning } \\
\text { System } \\
\text { - } \quad \text { Awareness of Flood Eventuality } \\
\text { - } \quad \text { Knowledge about Mock drills for } \\
\text { safety measures about sisters } \\
\text { - Rules and regulation for avoiding } \\
\text { construction activities in the } \\
\text { surrounding areas of streams and } \\
\text { river channels. } \\
\text { - De-silting and drudging activities } \\
\text { of government for river channels/ } \\
\text { flood spill channels. } \\
\text { - Safety audits to avoid flooding in } \\
\text { the flood prone areas } \\
\text { - Steps taken by government to } \\
\text { strengthen flood protection walls/ } \\
\text { bunds. } \\
\text { Evacuation measures in place for } \\
\text { emergencies } \\
\text { - Safe areas of evacuations in case of } \\
\text { emergency at the time of disasters }\end{array}$ & $\begin{array}{l}5 \\
0\end{array}$ & $\begin{array}{c}94 \\
95 \\
100 \\
100\end{array}$ & $\begin{array}{l}28 \\
30 \\
15\end{array}$ & $\begin{array}{l}70 \\
85\end{array}$ & $\begin{array}{l}45 \\
55\end{array}$ & $\begin{array}{l}55 \\
45 \\
76\end{array}$ \\
\hline
\end{tabular}




\begin{tabular}{|c|c|c|c|c|c|c|}
\hline $\begin{array}{l}\text { Status of DRR measures } \\
\text { - Construction activities around river } \\
\text { channels. } \\
\text { - De-silting and drudging activities } \\
\text { of government for river channels/ } \\
\text { flood spill channels } \\
\text { - Rules and regulations for the } \\
\text { removal of unauthorized and illegal } \\
\text { constructions around river } \\
\text { channels/ flood channels } \\
\text { - Maintenance and retrofitting } \\
\text { techniques used to strengthen flood } \\
\text { protection walls/ bunds } \\
\text { Emergency Operation areas for safe } \\
\text { evacuations in case of emergency at } \\
\text { the time of disasters. }\end{array}$ & 12 & $\begin{array}{c}5 \\
88\end{array}$ & 45 & 55 & 58 & 22 \\
\hline $\begin{array}{l}\text { Community Participation and } \\
\text { Preparedness } \\
\text { - } \\
\text { Participated in training programmes } \\
\text { conducted by NGOs/ CBOs/ } \\
\text { Government departments for DRR } \\
\text { measures. } \\
\text { - Capacities developed to act } \\
\text { appropriately in case of } \\
\text { communication of Early Warning } \\
\text { System } \\
\text { - Networks developed with } \\
\text { NGOs/CBOs for quick } \\
\text { communication in case of } \\
\text { emergencies. } \\
\text { Adopted disaster resilient building } \\
\text { and construction codes } \\
\text { Capacities of family members } \\
\text { developed to face disaster related } \\
\text { eventualities }\end{array}$ & 0 & 100 & 22 & 78 & 34 & 42 \\
\hline
\end{tabular}

Source: Field Survey by Research Team, May-June 2016 and September- October 2019

\section{Conclusion}

The results depict that State machinery have been created for ensuring conducive atmosphere of implementing rules and regulations especially, zero tolerance towards illegal encroachments in the river channels. Community has been sufficiently informed about rules and regulations of not encroaching river channels and flood channels. Even civil society organizations and individuals have better perception of disaster-risk reduction methods. They have observed significant improvement in the strategies being adopted towards disaster risk reduction, protective and preparedness measures. Steps like de-silting, drugging, maintenance of bund walls, clearance of river channels have been 
taken effectively by government agencies. However, awareness generation measures like safety audits, implementation of building codes and development of emergency resettlement centres are not being looked into effectively. Although early warning system equipment have been installed, but people are not aware as to, how such warning will be communicated and what measures are required during the warning period.

However the findings have some, limitations as identifying an attributing causality for an outcome is difficult especially with a time gap. The outcome of an action could be, as a result of a series of combined interventions. This is the first study of this nature, on community participation and preparedness, post September 2014 flood in Kashmir, hence in the absence of similar studies, the findings from the study requires further testing in similar situations.

\section{Recommendation}

- Strengthening the flood infrastructure in the Jhelum Basin to cope up, with the probability of next extreme flooding event of the magnitude observed in 2014. This includes the preparation of an integrated Disaster Preparation Plan (DPR) for the construction of the alternate flood channel for increasing the carrying capacity of the main tributary rivers with main rivers in the plain areas of Kashmir Valley.

- Dredging of the existing river channels, flood channels, wetlands and strengthening of breached and weak embankments must be carried out annually before the on-set of monsoons . Encroachments in the river channels by community for commercial agricultural, must be stopped and the river channels must be freed from such obstructions. Proper maintenance of these riverbanks is very much necessary and retaining walls needs to be retrofired, constructed to reduce the flooding conditions.

- The management of the water bodies/lakes and wetlands in the Jhelum river Basin should be brought under one regulatory authority for their integrated management.

- The government, with the help of academia/research institutes, must consider undertaking a scoping study to assess the probability of flooding in immediate future, based on the understanding, to be developed from the interactions of ground water, surface water and the landslide prone areas in the Jhelum river basin.

- SDMA and district authorities must urgently operationalize, the Flood Early Warning System (FEWS) for Jhelum River Basin, and also find out effective communication methods to inform community . 
- The State Government must initiate on priority (with the help of leading academic institutions), to undertake transparent flood zonation and flood vulnerability assessments of people and places at village level, so that the flood risk reduction is integrated with developmental planning, at village level in all District Development Plans.

- Knowledge driven all-inclusive multidisciplinary flood planning needs to be initiated on priority basis, by engaging technocrats with relevant expertise, to develop insights into flooding mechanisms in the Jhelum river basin, building on comprehensive existing studies.

- NGOs and CBOs and local communities must be encouraged to launch awareness generation campaigns on Disaster Management and riskreduction measures, converging both local and traditional knowledge with modern scientific knowledge. Effective support from SDMA and academia must be strengthened for these trainings. Such awareness should be generated and demonstrated with the help of local folk theatre, integrating the art with the theme of disaster risk reduction. Regular awareness campaign should be encouraged regarding safety measures against potential hazards using students body from schools and institutes of higher educations, media, campaigns, development and distribution of leaflet, posters, meetings, workshop on priority basis.

- Emergency Operation Site (EOS) should be identified, after identifying disaster vulnerability sites for future eventuality, and these sites should be fully prepared with all multipurpose emergency services like appropriate shelters, medical support, drinking water and appropriate bedding and food.

\section{Acknowledgement}

Author acknowledges, the funding support provided by Indian Council of Social Sciences Research. New Delhi-India. The present study is part outcome of an on-going Senior Research Fellowship Project.

\section{References:}

1. Bahadur, A. (2008) Accountability for DRR, IDS Research Report for Christian Aid. Brighton: Institute for Development Studies. https://www.researchgate.net/publication/275831843_The_Resilience _Renaissance_Unpacking_of_Resilience_for_Tackling_Climate_Cha nge_and_Disasters_Brighton_IDS_SCR_Working_Paper, accessed on 16th April, 2020

2. Douglas, R.H., (1990). The Stormy Weather Group (Canada). In Radar in Meteorology, D. Atlas (Ed.), Amer. Meteor. Soc., 61-68. 
http://www.radar.mcgill.ca/who-we-are/history.html, accessed on 23rd April, 2020

3. Dutta, Mondira (2019), Disaster Risk Reduction and Resilience Building among the Coastal Zone Communities in Lakshwadeep and Kerala, in Disaster Risk Reduction: Community Resilience and Responses (ed) by Bupinder Zutshi, Akbarudidn Ahmed and S Ananda Babu, Palgrave Macmillan, ISBN: 978-981-10-8844-5,

4. Intergovernmental Panel on Climate Change (IPCC). (2007c), "Summary for policymakers". In S. Solomon, D. Qin, M. Manning, Z. Chen, íspị. Marquis, et al. (Eds.), Climate change 2007: The physical science basis. Working Group, I contribution to the Intergovernmental Panel on Climate Change Fourth Assessment Report (pp. 1-18). Cambridge, U.K.: Cambridge University Press.

5. IPCC (2012) "Summary for policymakers. Managing the risks of extreme events and disasters to advance climate change adaptation", in C.B. Field, V. Barros, T.F. Stocker, D. Qin, D.J. Dokken, K.L. Ebi, M.D. Mastrandrea, K.J. Mach, G.-K. Plattner, S.K. Allen, M. Tignor and P.M. Midgley (eds) Special report of Working Groups I and II of the Intergovernmental Panel on Climate Change. Cambridge, UK, and New York: Cambridge University Press (www.ipcc-wg2.gov/SREX/images/uploads/SREX-

SPMbrochure_FINAL.pdf), accessed on 10th April 2019

6. Jackson, D. (2011) Effective financial mechanisms at the national and local level for disaster risk reduction. Geneva: United Nations Office for Disaster Risk Reduction

(www.unisdr.org/files/18197_202jackson.financialmechanismstosup. pdf), accessed on 15th April, 2020

7. Kamaljit Ray, S. C. Bhan and B. K. Bandopadhyay, (2015), The catastrophe over Jammu and Kashmir in September 2014: a Meteorological observational analysis, Current Science, VOL. 109, NO. 580 3, https://www.jstor.org/stable/24906113?seq=1, accessed on 12th October 2018.

8. Kent, G. (2001) The human right to disaster mitigation and relief, Environmental Hazards 3(3):

137-138; http://dx.doi.org/10.3763/ehaz.2001.0315, accessed on 5th arch, 2020

9. Khan, D. (2013) Opinion: integrating climate-smart DRM in key sectors - what does it take?,. London: Climate and Development Knowledge Network (http://cdkn.org/2013/06/opinion-integratingclimate-smart-drm-in-key-sectors-what-does-it-take);

10. Mitchell, T. and Tanner, T. (2006) Overcoming the barriers: mainstreaming climate change adaptation in developing countries. London: Tearfund. 
11. Mitchell, T., Jones, L., Lovell, E. and Comba, E. (2013) Disaster risk management in post-2015 development goals: potential targets and indicators. London: Overseas

12. National Disaster Management Authority ( NDMA, 2016): National Disaster Management Plan, 2016. A publication of the National Disaster Management Authority, Government of India. May 2016, New Delhi,

https://ndma.gov.in/images/policyplan/dmplan/National\%20Disaster \%20Management\%20Plan\%20May\%202016.pdf, accessed on 23rd April 2020.

13. National Disaster Management Act, Government of India (2006), Disaster Management Act, 2005, https://www.ndmindia.nic.in/images/The\%20Disaster\%20Manageme nt\%20Act,\%202005.pdf, accessed on 20th April 2020.

14. Raza, M., Ahmad, A. and Mohammad, A.; (1978.) The Valley of Kashmir: A Geographical Interpretation, Vol,1: the Land, Vikas Publishing House Pvt, Ltd., New Delhi, pp. 1-59.

15. Stern, N. (2006). The economics of climate change: The Stern Review. New York: Cambridge University Press.

16. The Daily Excelsior ,Newspaper, Srinagar, Jammu \& Kashmir, 7th September, 2014

17. The Tribune, Newspaper, Chandigarh, Union Territory of Chandigarh, June, 02, 2017

18. United Nations Office of Disaster Risk Reduction (UNDRR), (2015) : Sendai Framework for Disaster Risk Reduction (SFDRR) 2015-30. https://www.undrr.org/publication/sendai-framework-disaster-riskreduction-2015-2030, accessed on 20th April 2020

19. Zutshi, Bupinder, Ahmad Akbaruddin, Srungarapati, Ananda Babu, (2019), Disaster Risk Reduction Community Resilience and Responses, Published by Palgrave-Macmillam. ISBN: 978-981-108844-5 